
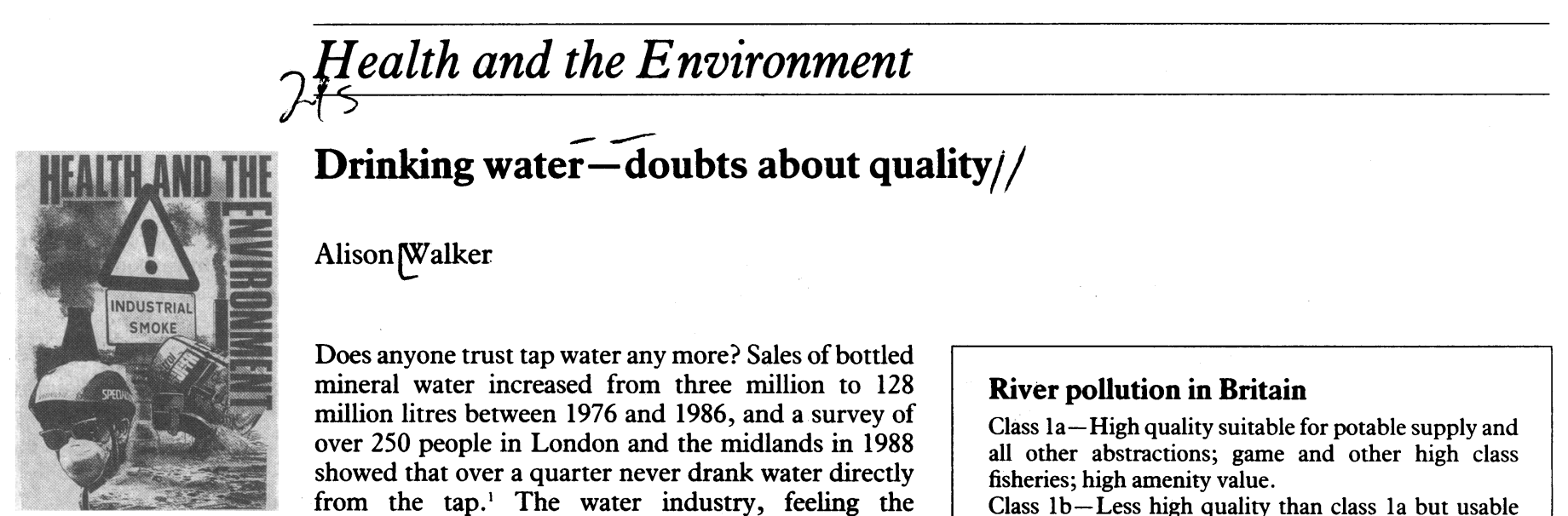

\author{
Alison Walker
}

Does anyone trust tap water any more? Sales of bottled mineral water increased from three million to 128 million litres between 1976 and 1986, and a survey of over 250 people in London and the midlands in 1988 showed that over a quarter never drank water directly from the tap. ${ }^{1}$ The water industry, feeling the consequences of privatisation, stringent European Community directives, and growing pressure from environmental groups, is finding it hard to convince the public that tap water is still safe, let alone palatable. Scares like the accidental contamination of water at Camelford with aluminium have not helped either. But are the public's fears justified? Is drinking water any less safe than it was 50 years ago?

\title{
Water sources
}

Some impurities in tap water are inevitable. These derive both from the different sources of water and from the treatment process.

Domestic water is extracted from groundwater, reservoirs, or rivers depending on local geography. ${ }^{2}$ Groundwater is pumped up from aquifers or water permeable rocks. These are mostly found in the chalk regions of the south of England and the sandstones of the east midlands. They provide nearly a third of the water in England and Wales. Natural filtering takes place through the rock, but contamination is still possible. Supplies from aquifers near waste disposal sites, for example, may be contaminated if drainage water from the sites percolates through them. A survey carried out by the Department of the Environment in 1987 of 100 landfill sites in Britain showed that a disturbingly high percentage $(62 \%)$ took no measures to prevent groundwater ingress. ${ }^{3}$ Groundwater in agricultural areas is also at increased risk of contamination as nitrate based fertilisers and pesticides can leach into the supply.

Reservoirs are mainly found in upland areas of Scotland, Wales, northern England, and the south west, where the local geography makes damming of

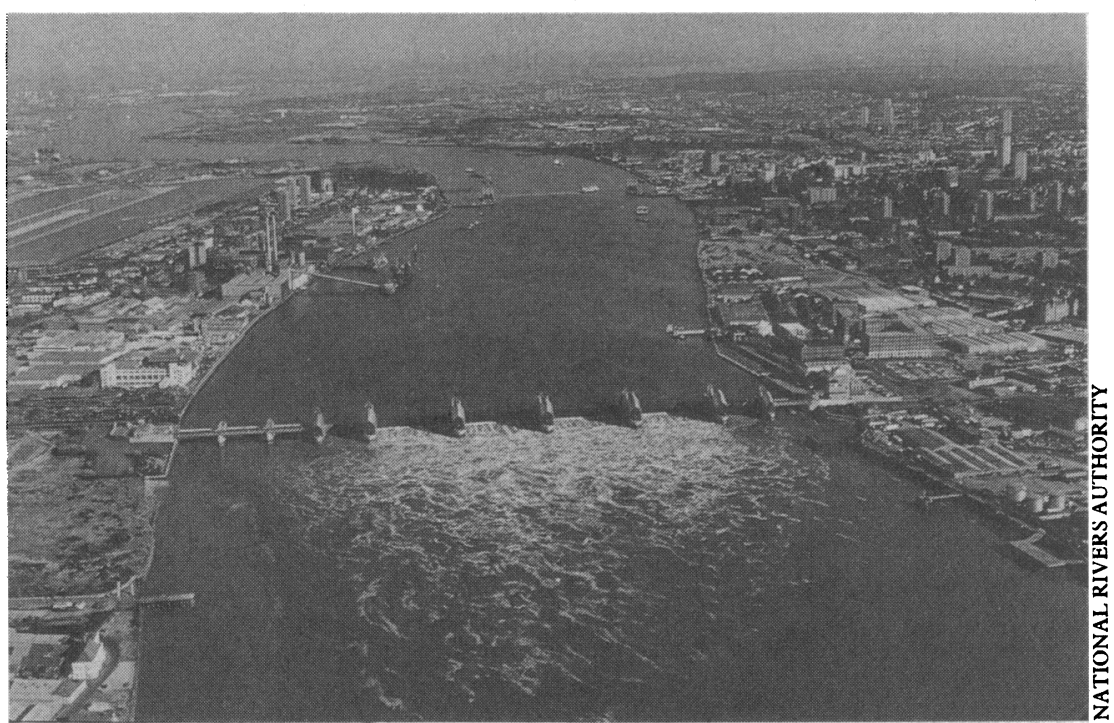

How many times will this water have been recycled before it reaches the sea?

British Medical Journal, Eondor WC1H 9JR Alison Walker, MRCP, Correspondence to: Department of Paediatrics, W2 1NY

BMF 1992;304:175-8

\section{River pollution in Britain}

Class la-High quality suitable for potable supply and all other abstractions; game and other high class fisheries; high amenity value.

Class $1 \mathrm{~b}$-Less high quality than class la but usable for substantially the same purposes.

Class 2-Suitable for potable supply after advanced treatment; supporting reasonably good coarse fisheries; moderate amenity value.

Class 3-Polluted to an extent that fish are absent or only sporadically present; may be used for low grade industrial abstraction; considerable potential for further use if cleaned up.

Class 4-Grossly polluted and likely to cause a nuisance.

River pollution in Britain is graded on the above five point scale. The water from roughly a third of Britain's rivers fails to reach classes la and $1 \mathrm{~b}$. Of the $41500 \mathrm{~km}$ of rivers graded by the National Rivers Authority in $1989-90,600 \mathrm{~km}$ were in class $4,10500 \mathrm{~km}$ in class 2 , and $3500 \mathrm{~km}$ in class 3 , and the remainder in classes la and $1 \mathrm{~b}$ (about $13500 \mathrm{~km}$ each). ${ }^{4}$

valleys practicable. The water tends to be soft and peaty and is relatively uncontaminated, being situated away from industrial areas.

Rivers such as the Thames, Ouse, and Severn provide water for the dense urban populations of the towns and cities located nearby. River water is often recycled through sewage works and used again by towns further downstream (box 1). Britain is fortunate being an island-the river pollution problems faced in this country are dwarfed compared with those tackled by countries bordering on international rivers such as the Rhine in Europe.

\section{Water treatment}

No set procedure exists for water treatment as water varies so much around the country, but in general groundwater needs less treatment than surface water. A preliminary storage stage (during which most bacteria will die) may begin the treatment but is not incorporated into all plants. Modern plants of various designs are based on chemical coagulation-for example, with aluminium sulphate - followed by sedimentation and filtration. Other stages are added to remove iron and manganese, to control taste and odour, and to remove organic matter. Older treatment plants use slow sand filtration through several layers of finely graded sand, but because these require substantial areas of land and have high labour costs no new plants of this type have been installed for years. The final stage in all treatment works is disinfection. Chlorine is the commonest disinfectant used, although ozone or exposure to ultraviolet light are becoming more popular. Before water leaves the treatment works its $\mathrm{pH}$ and hardness are adjusted and fluoride may also be added.

Serious accidental contamination of drinking water either before or at the treatment works is fortunately rare. Much more of a public health concern are the possible long term effects of chronic exposure to 
substances present in drinking water at low concentration. Legislation exists to regulate the concentration of these impurities, and the task of adhering to required standards falls to the water industry.

\section{The water industry}

The water industry in Britain was privatised three years ago. Drinking water is now supplied by 10 regional water service companies and 29 smaller water companies, all of which have a statutory duty to provide wholesome water to the public. ${ }^{5}$ Though the water industry has always been a target for environmental campaigners, pressure on it has increased since privatisation. The water companies are required to comply with physical, chemical, and biological parameters for water intended for drinking, washing, and cooking purposes as defined by the European Community drinking water directive. Sixty six parameters are described in the directive of mandatory standards for all European suppliers (box 2). While the water companies seek derogations or exemptions from some of the standards they consider to be too stringent, pressure groups and the media are quick to point to companies finding difficulties with compliance-and are able to feed the public's anxieties.

The Department of the Environment has issued a programme for improving drinking water intended to bring virtually all drinking water supplies up to standard by 1995 . A total of $£ 1 \cdot 8 \mathrm{bn}$ is being invested over the next five years - which ultimately will have to be paid by the customer. In the meantime water companies can apply for derogations in circumstances where the nature of the source from which the water is extracted makes it difficult to comply with the European Community directive or where there is a delay while steps are taken to ensure compliance with microbiological and toxic levels.

One of the toughest standards is for pesticides. A maximum admissible concentration for pesticides in water of $0.1 \mu \mathrm{g} / \mathrm{l}$ for individual pesticides and $0.5 \mu \mathrm{g} / \mathrm{l}$ for the total pesticide concentration is required by the European Community directive. In 1990, 34 pesticides were detected at concentrations above $0 \cdot 1 \mu \mathrm{g} / \mathrm{l}$ by the government's drinking water inspectorate. ${ }^{6}$ The pesticides most often detected are those used on roadside verges and railways such as atrazine and simazine. The low levels required by the directive amount to a virtual ban on pesticides in water, according to Peter Matthews, director of quality at Anglian Water. Professor Ronald Packham, former chief scientist at the Water Research Centre, believes that the directive is inflexible and suffers from having no built in scheme for revision. World Health Organisation guidelines laid down in 1984, he says, were far more realistic and even then had an enormous safety factor. The media, he added, have tended to highlight instances of non-compliance, equating them with a health hazard - which is not necessarily the case.

\section{Health risks}

While disputes continue over legislation governing drinking water standards, medical evidence linking contamination with possible health risks has been gathering, although it is still limited.

Little doubt exists over the health risk from the presence of some contaminants in drinking water; infectious diseases, for example, are known to be transmitted by a wide range of micro-organisms found in contaminated water. For chemical constituents the picture is not always clear. Some chemicals can now be detected in drinking water at concentrations of a million billionth of a gram per litre. In many cases, however, the ability to detect these substances in water
Key parameters used for the assessment of water quality

Coliforms

Faecal coliforms

Colour

Turbidity

Odour (quantitative)

Taste (quantitative)

Nitrate

Aluminium

Iron

Manganese

Lead

Polycyclic aromatic

hydrocarbons (PAH)

Pesticides

has outstripped our knowledge of their medical significance.

\section{Microbiological contaminants}

John Snow elegantly showed the waterborne cause of the 1854 cholera epidemic in London by removing the handle of the Broad Street water pump. Any micro-organism transmitted by the faecal-oral route has the potential to cause infection, but modern water treatment plants aim at disinfecting water sufficiently before it reaches the public. Escherichia coli is tested for as an indicator of possible faecal contamination before water leaves the treatment plant.

A review of outbreaks of waterborne disease in Sweden between 1975 and 1984 showed that in almost all cases the causes were technical hitches at the treatment plants. ${ }^{7}$ These included broken sewage pipes, blockage of wastewater pipes, or sudden pollution of water intakes coinciding with inadequate chlorination Although campylobacter was the most commonly identified causative organism, previously ignored pathogens such as giardia, Norwalk agents, and cryptosporidium have been shown to be important in the past few years.

Cryptosporidium has also been incriminated as the cause of contaminated drinking water in Britain. In 1989 an outbreak of cryptosporidiosis in Swindon and Oxford "caught the water industry napping," according to some critics. The organism is thought to have entered the water supply after the Thames was contaminated with farmyard slurry. Most people exposed to the parasite simply develop a self limiting gastroenteritis lasting up to a week, but in immunocompromised patients it can cause severe diarrhoea and dehydration. The organism survives chlorine treatment and is not routinely tested for at treatment plants. Tap water was incriminated as the cause of the outbreak in the Thames region, naturally causing public concern. The incident was fully investigated by an expert panel chaired by Sir John Badenoch. ${ }^{8}$

\section{Chemical contaminants}

The risks of chemical contamination of drinking water are not as clearly understood as those of microbiological contamination. Nevertheless environmental pressure groups will argue that pioneers in public health campaigned for cleaner water long before the pathogens causing infectious disease were discovered. Already some chemicals in water supplies are known to be potentially harmful. ${ }^{9}$

\section{ALUMINIUM}

Many water treatment works add aluminium sulphate to the water as a coagulant to help remove suspended matter. Most of the aluminium is removed in the subsequent filtration and clarification processes, but residual amounts may pass into the water supply. The current European Community directive specifies a maximum acceptable concentration of $0.2 \mathrm{mg} / 1$, although this level is based on the incidence of dirty water problems and not on health effects. 


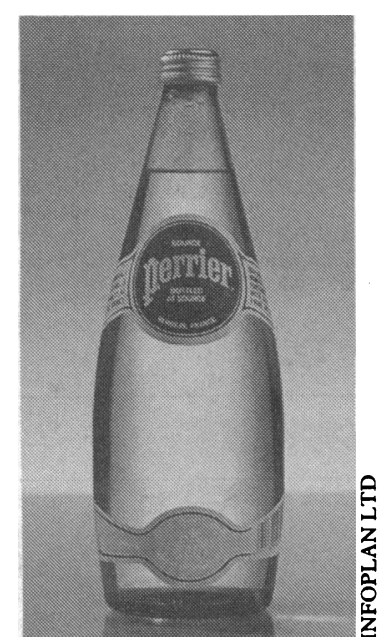

Bottled water is over 1500 times more expensive than tap water
Most evidence surrounding the health risks from aluminium in drinking water link it with neurotoxicity and particularly Alzheimer's disease. "Dialysis dementia" has been described in patients on renal dialysis using water with a high concentration of aluminium. More recent epidemiological evidence showed that the risk of Alzheimer's disease is 1.5 times higher in districts where the mean aluminium concentration in drinking water was greater than $0.11 \mathrm{mg} / 1$ compared with districts where it was less than $0.01 \mathrm{mg} / \mathrm{l} .^{10}$ This study has been criticised for several reasons, including for ignoring family history, for having a low case ascertainment, for ignoring patients who had not had computed tomography, and for being too simplistic.

Only a few people consumed large amounts of water after the accident in 1988 at the Lowermoor works in Camelford in 1988 when a lorry driver mistakenly discharged 20 tonnes of concentrated aluminium sulphate solution into the wrong tank. Up to 400 people still complain of symptoms, but whether this accident helps to clarify anything other than the acute effects of aluminium poisoning remains debatable. ${ }^{11}$

\section{NITRATE}

The maximum admissible concentration for nitrate in drinking water is $50 \mathrm{mg} / \mathrm{l}$ and is based on the risk of bottle fed infants developing methaemoglobinaemia. Nitrate in water can be converted in the stomach to nitrite, which readily combines with fetal haemoglobin converting it to methaemoglobin. When $10 \%$ of the total haemoglobin is in the methaemoglobin form, cyanosis occurs. Levels above $70 \%$ are lethal. Methaemoglobinaemia is extremely rare and there have been no cases of high nitrate causing any deaths in Britain since 1948. ${ }^{12}$

A more contentious issue is the link between gastric cancer and nitrate in the diet. Vegetables and drinking water are two of the main dietary sources of nitrate and nitrite, the other major source being the preservatives added to meat to prevent botulism and to enhance colour. Nitrate can be converted to nitrite by bacteria in the mouth and stomach. This nitrite in turn can be converted to $\mathrm{N}$-nitroso compounds, most of which are strongly carcinogenic in animals. International comparisons relate high levels of nitrate exposure to mortality from gastric cancer-for example, in Denmark, Hungary, and Italy. The findings have not always been consistent, and in Britain studies have not confirmed that environmental nitrates and nitrites play a major part in the risk of gastric cancer. ${ }^{13}$ The discovery that nitrate is synthesised in humans and that nitric oxide is a natural endogenous mediator of cellular communications ${ }^{14}$ raises further questions over the significance of exogenous nitrate in cancer.

\section{LEAD}

Most houses built before 1964 have some lead pipework. People most at risk from contaminated water supplies are those living in older houses in areas with acidic water, which include Scotland, the north of England, Wales, and the west country. ${ }^{12}$ There is little doubt about the toxicity of lead. The effects of acute exposure are well established, causing among other things abdominal pain, headache, irritability, and eventually coma and death. But the effect of long term low exposure is not fully known.

The main concern is over the possible relation between exposure to lead and behavioural and learning difficulties in children. Since the first studies in the late 1970s evidence has accumulated pointing to an inverse relation between blood lead concentrations and measures of intelligence. ${ }^{\text {is }}$ A general lowering of the acceptable concentration for lead in drinking water is likely to occur in the future.
HARDNESS OF WATER

Calcium, nitrate, silica, and conductivity are among the variables which correlate strongly with water hardness. Epidemiological evidence has shown an inverse relation between the hardness of water and mortality from cardiovascular disease-towns with very soft water were shown to have about $10 \%$ higher mortality than towns with harder water after taking into account age, sex, and socioeconomic and climatic factors. ${ }^{16}$ Houses fitted with water softeners should keep one tap supplying hard water for cooking and drinking.

\section{PESTICIDES}

In 1990, amid much publicity, the BMA reported on the possible health risks of pesticides. ${ }^{12}$ Having comprehensively reviewed the literature, the association found that most studies of the chronic effects of pesticides were inconclusive and that more specific information was needed. The BMA report prompted a new green card reporting system with a central Pesticides Incident Monitoring Unit. The green card is analogous to the yellow card system already used to gather information about adverse drug reactions. Using the green card system, doctors should report evidence of adverse effects from exposure to pesticides in their patients to the new monitoring unit. This replaces previous arrangements whereby several agencies collected data in an uncoordinated way. The new unit will be able to monitor the effects of exposure to pesticides on the public and improve the current level of knowledge on the toxicity of pesticides.

\section{Conclusion}

The media, fuelled by environmental pressure groups, urge the government to ensure that water resources are not polluted, that water treatment works do not save money by cutting corners, and that water quality comes up to standard. On the other hand the water industry continues to try to reassure the public that drinking water remains as good as it was 50 years ago, if not better. The results of two recent surveys have lent support to the industry, finding tap water to be mostly of good quality although with a few exceptions. One report from the Drinking Water Inspectorate found that standards were met in $99 \%$ of the 3.3 million tests it carried out in England and Wales in 1990 . It also, however, was considering prosecuting four water companies for failure to meet drinking water standards. Another survey of London's drinking water in 1989 by the Institution of Environmental Health Officers found that nearly $60 \%$ of the samples taken failed to comply with the standard for the herbicides atrazine and simazine. ${ }^{17}$ Yet the report was still able to conclude that, overall, London's water was "wholesome" with no risk to health.

The decision whether to trust tap water is ultimately left up to the consumer. But if fad or simply fancy advertising persuades you to buy bottled water, spare a thought for your purse. A litre of bottled water may cost $50 \mathrm{p}$ or more, while a litre of tap water costs as little as $0.03 p$.

I am grateful to Professor Ronald Packham for his help in compiling this article.

1 Wheeler D. Risk assessment and the public perception of water quality. Annual symposium of the Institution of Water and Environmental Managemen London: IWEM, 1990:2-1-2-13.

2 Hall C Running water. London: Robertson McCarta, 1989.

2 Hall C. Running water. London: Robertson McCarta, 1989. . roft B, Campbell D. Characteristics of 100 landfill sites. In: Proceedings of
1990 Harwell waste management symposium. Harwell: United Kingdom 1990 Harwell waste managemen

4 National Rivers Authority. Annual reports and accounting. London: National National Rivers Authority.
Rivers Authority, 1990 .

5 Water Services Association. Waterfacts. London: Water Services Association, 1990. 
6 Department of the Environment. Drinking water 1990-a report by the chief inspector, drinking water inspectorate. London: HMSO, 1991.

7 Andersson Y, Stenströ TA. Waterborne outbreaks in Sweden-causes and etiology. Waler Science and Technology 1987;19:575-80.

8 Group of Experts. Report on crvptospordium in water supplies. London: HMSO, 1990.

9 Packham RF. Chemical aspects of water quality and health. Annual symposium of the Institution of Water and Environmental Management. London: IWEM

10 Martyn C, Osmond C, Edwardson JA. Geographical relation between Alzheimer's disease and aluminium in drinking water. Lancet 1989;i:59-62.

11 Lowermerr Health Advisory Group. Water pollution at Lowermoor North Comwall. Second report. London: HMSO, 1990.
12 British Medical Association. Pesticudes, chemicals, and health. London: Edward Arnold, 1990

3 Forman D, Al-Dabbagh S, Doll R. Nitrates, nitrites and gastric cancer in Great Britain. Nature 1985;313:620-5.

14 Collier J, Vallance P. Physiological importance of nitric oxide. BMf 1991;302 $1289-90$

15 Lee WR, Moore MR. Low level exposure to lead. BMJ 1990;301:504-5.

16 Pocock SJ, Shaper AG, Cook DG, Packham RF, Lacey RI, Powell P, et al. British Regional Heart Study: geographic variations in cardiovascula British Regonal Heart Study. geographic variations in cardi

17 Working party on London wide drinking water. London's drinking water. London: Institution of Environmental Health Officers, 1990.

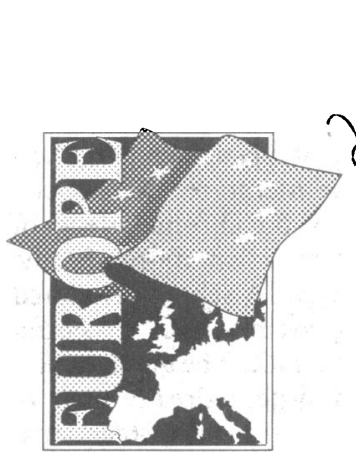

This is the seventh in a series of articles looking at medical issues in Europe.
The Coronary Prevention Group 102 Gloucester Place, (London)W1H 3DA Michael O'Connor, MSC, director

BMF 1992;304:178-80

\section{Medicine in Europe \\ Europe and nutrition: prospects for public health //}

\section{Michae O’Connor}

After the second world war the major nutritional problems in Europe, if not the United Kingdom, arose from deficiencies of protein, minerals, and vitamins. As western European economies recovered the problems became more those of overconsumption of nutrients such as fat, sugar, and salt. The problems are now ones of quality, not quantity, but the legacy of deprivation is still present. Much food policy is still geared towards producing large quantities of food and protecting the economic interests of farmers and food manufacturers rather than promoting healthy diets, protecting the environment, or even reflecting consumer demand.

\section{European dietary patterns}

There are no standardised studies on consumption in Europe that can be used to produce compatible data on food or nutrient intake. It is possible, however, to use food balance sheets produced by the Food and Agriculture Organisation of the United Nations. These tables show the nature of the food supply and so may not fully represent what people are actually eating, but they provide a useful picture of trends in food consumption (figs 1 and 2; table).

Compared with just after the war Europeans now eat more food of animal origin and less of vegetable origin. They eat every day the foods they used to eat on festive days. There are large regional variations. Mediterranean countries still derive a larger part of their energy from vegetable products than do northern European countries. The "Mediterranean diet" is believed to be healthier. Unfortunately, there are signs that these countries, and those in eastern Europe, are adopting unhealthy northern European diets. ${ }^{2}$ People in southern and eastern European countries suffer most

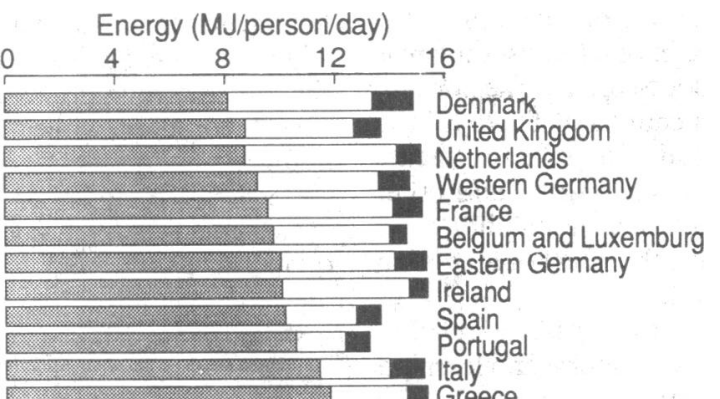

Vegetable products $\square$ Animal products Alcohol

FIG 1-Total energy available per person per day from vegetable and animal products and from alcohol in European countries, 1979-81 Source: World Health Organisation.

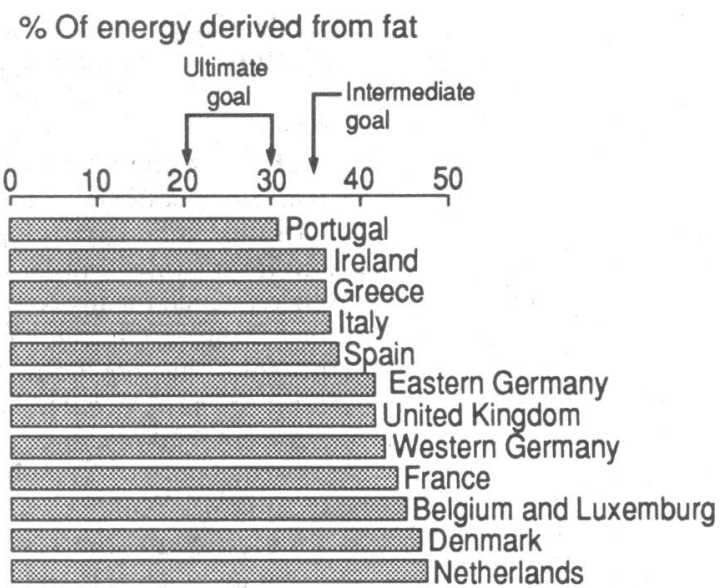

FIG 2-Estimated percentage of total energy derived from fat in some European countries

Source: World Health Organisation

Intermediate and ultimate nutrient goals for Europe

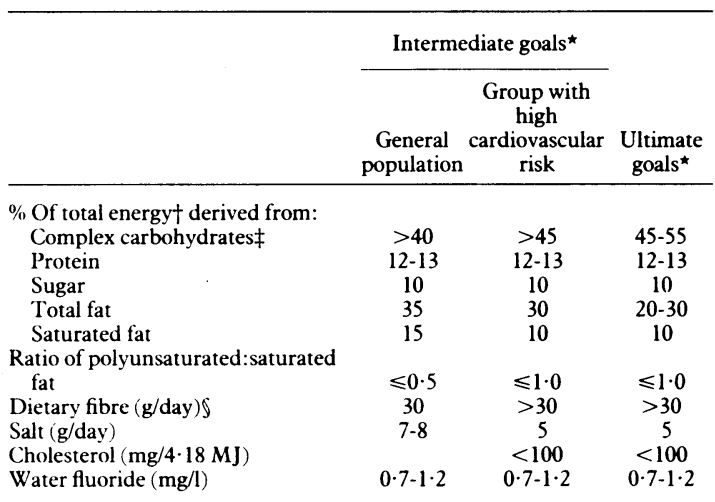

*Several ultimate and intermediate goals for the general population and the high risk group are the same: alcohol intake should be limited; iodine prophylaxis should be given when necessary; nutrient density should be increased; and body mass index should be $20-25 \mathrm{~kg} / \mathrm{m}^{2}$ (though this value is not necessarily appropriate for the developing world, where the average index may be $18 \mathrm{~kg} / \mathrm{m}^{2}$ ).

tAll values given refer to alcohol free total energy intakes.

These figures are implications of the other recommendations.

Values are based on analytical methods that measure non-starch polyvacharide and enzyme resistant starch produced by food processing or cooking methods.

from obesity, but as a whole the region compares favourably with other developed regions such as North America and Australasia. ${ }^{3}$

\section{Nutrition policy in the EC}

In the context of current wider political debates some people may question the need for European nutrition policies. These are essential to maintain high 